\title{
Novel Cataract Mouse Model Using ddY Strain: Hereditary and Histological Characteristics
}

\author{
Tomohiro KONDO ${ }^{1)}$, Hiroaki NAGAI ${ }^{1)}$, Hiroshi MORIOKA ${ }^{1)}$, Ken Takeshi KUSAKABE ${ }^{1)}$ and Toshiya OKADA ${ }^{1) *}$ \\ ${ }^{1)}$ Department of Integrated Structural Biosciences, Division of Veterinary Science, Graduate School of Life and Environmental Sciences, \\ Osaka Prefecture University, 1-58 Rinku Ourai Kita, Izumi-Sano, Osaka 598-8531, Japan
}

(Received 3 September 2009/Accepted 10 October 2009/Published online in J-STAGE 27 November 2009)

\begin{abstract}
A novel cataract model was identified in the ddY strain (outbred colony) reared at Osaka Prefecture University. Opacity appeared as a white pinpoint focus in the unpigmented eyes of cataract mice at 6 weeks of age. All mice, fully viable and fertile, were bilaterally affected by the time they were 10 weeks of age. There were no gender differences in the incidence of cataracts. Histologically, 5-month-old cataract mice showed vacuolation of epithelial cells, disruption of lens fibers, and dislocation of the lens nucleus to the posterior lens cortex. To elucidate the mode of inheritance, heterozygous mutant hybrids between cataract mice and wild-type ddY mice, as well as offspring between the heterozygous mutants, were analyzed. No affected mice were observed among the heterozygous mutants, and the ratio of affected to unaffected mice was 1:3 among offspring between heterozygous mutants. For linkage analysis, we produced backcross progeny [cataract mouse $\times$ (cataract mouse $\times$ MSM/Ms mouse)], and concluded that the cataracts are inherited by an autosomal recessive gene. Moreover, the locus of the cataract gene, $m c t$, was mapped to the $3.91 \mathrm{cM}$ region encompassed by D2Mit467 and D2Mit320 on mouse chromosome 2 by linkage analysis. Thus, the present cataract mice represent a novel cataract mouse model, and have been designated Morioka cataract (MCT) mice.
\end{abstract}

KEY WORDS: hereditary cataract mouse model, linkage analysis, MCT mouse.

J. Vet. Med. Sci. 72(2): 203-209, 2010

A cataract is one of the most common eye defects and causes of lens opacity [12]. Lens opacity may lead to blindness [10]. Causes of cataracts include congenital defects, senility, metabolic disorders and exposure to a variety of physical and chemical agents [22]. About 10 to 30 percent of childhood blindness cases are due to congenital cataracts [1], and approximately one-quarter to one-third of congenital cataract cases are hereditary [2, 4, 9]. Thus, establishment of an animal model of cataracts is an effective method to elucidate human cataractogenesis [5]. Many types of cataracts, that may be inherited and that have been evaluated developmentally, histologically and genetically, have been studied in mice $[7,11,14,16,18]$. In the cataract lens, various morphological features, including the posterior dislocation of the nucleus [23], vacuolation of the epithelium [15] and vacuolation of the lens [22] are observed.

In our laboratory, mice with cataracts were identified in a colony of ddY mice in 1997 . The cataract mice were isolated from the colony, and bred by random mating. In the present study, we investigated the hereditary and histological characteristics of these cataract mice.

\section{MATERIALS AND METHODS}

Animals and husbandry: Cataract mice, a novel cataract strain derived from mice of the ddY strain (outbred colony),

\footnotetext{
* CoRrespondence to: OKADA, T., Department of Integrated Structural Biosciences, Division of Veterinary Science, Graduate School of Life and Environmental Sciences, Osaka Prefecture University, 1-58 Rinku Ourai Kita, Izumi-Sano, Osaka 5988531, Japan.

e-mail: okada@vet.osakafu-u.ac.jp
}

were used. Normal ddY mice (wild-type) were purchased from Japan SLC (Hamamatsu, Japan) and were used as controls. The MSM/Ms mice were kindly donated by Dr. Moriwaki (National Institute of Genetics, Mishima, Japan) and used for linkage analysis. All the animals were maintained under regulated room temperature $\left(24 \pm 1^{\circ} \mathrm{C}\right)$, humidity $(55$ $\pm 5 \%$ ) and lighting (from 06:00 to 20:00). Animals were given a commercial diet (CE-2; Clea, Osaka, Japan) and water ad libitum. The present study was performed in accordance with the Guidelines for Animal Experimentation of Osaka Prefecture University, Japan.

Observations and histological studies: Mice were observed with the naked eye under non-anesthetic conditions more than once a week after their eyes opened at approximately 2 weeks of age. For histological studies, 5week-old and 5-month-old cataract mice were used. Under isoflurane anesthesia, the mice were infused with heparinsaline, followed by $10 \%$ neutral buffered formalin. Eyes were then removed and immersed in the same fixative for two days. Eyes were dehydrated through a graded series of ethanol, soaked in butyl alcohol and embedded in paraffin (Tissue Prep, Fisher Scientific, Fair Lawn, NJ, U.S.A.). Sections $(6 \mu \mathrm{m})$ were cut in a plane perpendicular to the anterior-posterior axis of the eye and were stained with hematoxylin and eosin.

Mating experiment: To elucidate the mode of inheritance, cataract mice were mated with wild-type ddY mice in order to obtain heterozygous mutants. Heterozygous mutants were then mated in order to obtain the segregation ratio of affected and unaffected mice. The incidence of lens opacity was determined with the naked eye by visual examination more than once a week from 2 weeks until 5 months of age. 
Linkage analysis: Genomic DNA was extracted from the tail of affected backcrossed progeny [cataract mouse $\times$ (cataract mouse $\times$ MSM/Ms mouse)]. For linkage analysis, 54 polymorphic microsatellite markers (Sigma Aldrich Japan, Tokyo, Japan) were selected. These markers had typed polymorphisms between the cataract and MSM/Ms mice. Markers and their approximate centimorgan (cM) distances from the centromeric telomere are shown in Table 3. For the primary examination, 20 to 60 DNA samples from affected mice were used. For further mapping, 23 microsatellite markers on chromosome $2(\mathrm{Chr} 2)$ were added. For the secondary check, 135 to 332 DNA samples from affected mice were used. PCR was performed in a $10-\mu l$ reaction mixture containing $50 \mathrm{ng}$ of template DNA, $1 \mathrm{mM}$ dNTPs, $0.5 \mathrm{U}$ Taq polymerase (Takara Bio Co., Otsu, Japan), and each primer at $6.6 \mu \mathrm{M}$. PCR amplification was carried out with an initial denaturation at $94^{\circ} \mathrm{C}$ for $3 \mathrm{~min}$, annealing for $45 \mathrm{sec}$ and extension at $72^{\circ} \mathrm{C}$ for $45 \mathrm{sec}$, followed by a final extension step at $72^{\circ} \mathrm{C}$ for $10 \mathrm{~min}$. Annealing temperatures varied with the markers. Each PCR product was mixed with $3 \mu l$ of loading buffer and electrophoresed on $8 \%$ polyacrylamide gels for $3 \mathrm{hr}$ at $120 \mathrm{~V}$. Gels were stained with ethidium bromide or with a silver staining kit (Daiich Pure Chemical Co., Tokyo, Japan). Significance of linkages was evaluated by a $\chi^{2}$ test of independence (degree of freedom=1) of frequencies of hetero- and homozygotes in the affected backcross mice.

\section{RESULTS}

Incidence of cataract: Both wild-type ddY (Fig. 1a) and cataract (Fig. 1b) mice are shown in Fig. 1, and the incidence of opacity with age is listed in Table 1. Opacity appeared as a white pinpoint focus in the pink eyes of mice at 6 weeks of age. The rate of progression of opacity in each eye was almost equal, and the size of the opacity in the eyes increased with age. All mice were completely affected by 10 weeks of age and manifestation was bilateral. There were no gender differences in the incidence of cataracts. All mice were fully viable and fertile. The mean litter size was 9.6, and the weaning rate was $82.1 \%$ at the first parity (data not shown). It was impossible to distinguish affected and unaffected mice by shape, size or any other bodily feature, except lens opacity. Opacities were very similar in shape in each affected mouse.

Histological findings: In the lens of 5-month-old cataract mice, the lens nucleus was abnormally eosinophilic and was moved to the posterior region of the lens, while the lens nucleus was almost normal in the lens of 5-week-old cataract mice (Fig. 2). In the anterior region of the lens of 5week-old cataract mice, some of the lens fibers were swollen, while in that of wild-type ddY mouse, lens fibers were normal (Figs. 3a and 3b). In the anterior region of the lens of 5-month-old cataract mice, epithelial cells were vacuolated, some of the lens fibers were swollen, and numerous pyknotic nuclei were observed, while in the wild-type ddY mouse, epithelial cells and lens fibers were normal, with no pyknotic nuclei observed (Figs. 3c and 3d).

Mode of inheritance: The results of the mating experiments are presented in Table 2. Heterozygous mutants between the cataract and wild-type ddY mice were phenotypically normal. The ratio of affected to unaffected mice
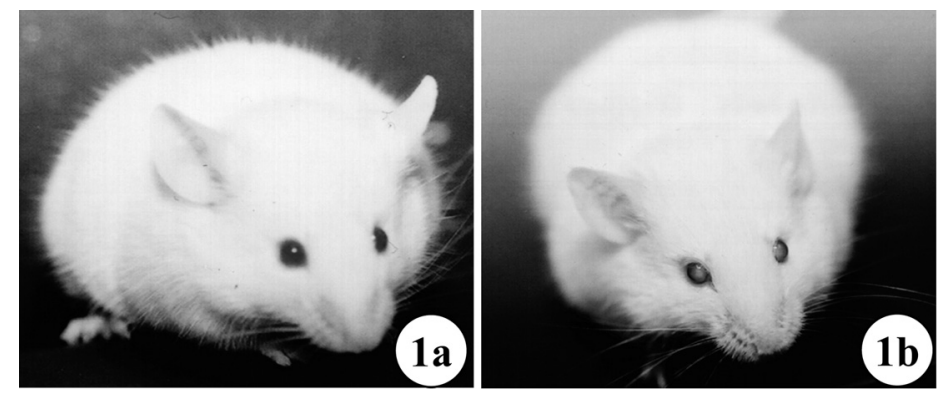

Fig. 1. Wild-type ddY and cataract mice. Wild-type ddY mouse (1a) has pink eyes with no opacity, whereas cataract mouse (1b) has pink eyes with opacity.

Table 1. Incidence of cataract in the cataract mouse with age

\begin{tabular}{lccccc}
\hline & \multicolumn{5}{c}{ Age (weeks) } \\
\cline { 2 - 6 } & 6 & 7 & 8 & 9 & 10 \\
\hline Normal & 198 & 51 & 3 & 1 & 0 \\
& $\left.(99,99)^{\mathrm{a}}\right)$ & $(27,24)$ & $(3,0)$ & $(1,0)$ & $(0,0)$ \\
Unilateral cataract & 7 & 12 & 0 & 0 & 0 \\
& $(3,4)$ & $(4,8)$ & $(0,0)$ & $(0,0)$ & $(0,0)$ \\
Bilateral cataract & 21 & 163 & 223 & 225 & 226 \\
& $(9,12)$ & $(80,83)$ & $(108,115)$ & $(110,115)$ & $(111,115)$ \\
\hline
\end{tabular}

$\mathrm{n}=226$ (female:111, male: 115$)$, a) female, male. 

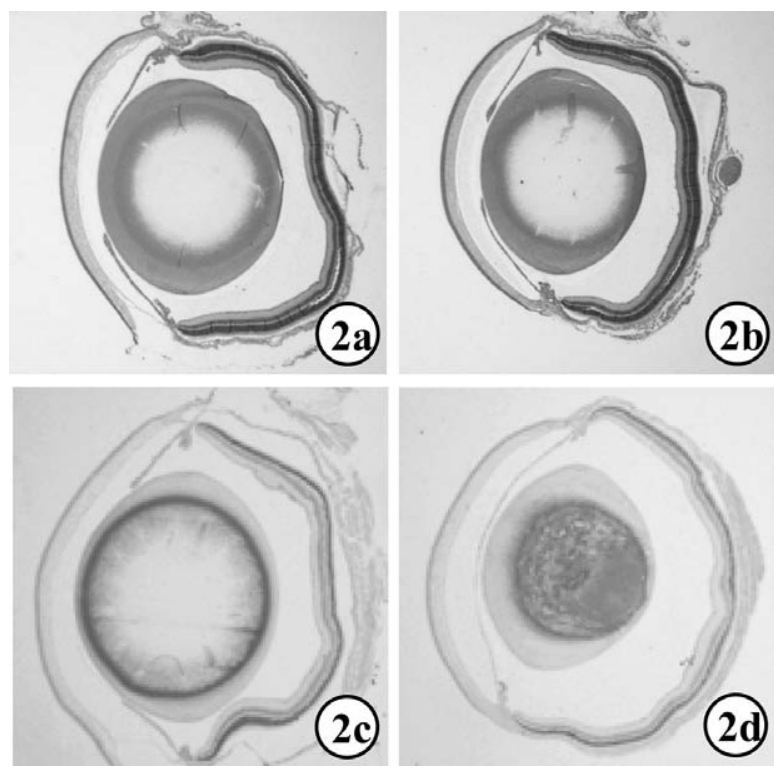

Fig. 2. Eye of wild-type ddY and cataract mice $(\times 7.5)$. Eosin staining in the lens of 5-week-old cataract mouse (2b) is similar to that in the lens of age-matched ddY mouse (2a). Eosin staining in the lens of 5-month-old cataract mouse (2d) is abnormally stronger than that in the lens of age-matched ddY mouse (2c). Lens nucleus of the 5-month-old cataract mouse is dislocated to the posterior region of the lens cortex (2d).

among the offspring between heterozygous mutants was approximately $1: 3$.

Linkage analysis: The results of a linkage test on each autosomal chromosome are shown in Table 3. The range of $\chi^{2}$ analysis in the polymorphic 54 microsatellite loci was 0 to 60 . The $\chi^{2}$ values of D2Jpk4 and D2Nds1, located on Chr 2 , were recorded at 60 and 15 , respectively. This indicates that there is a linkage between the mutant gene $(m c t)$ and $\mathrm{Chr}$ 2. Therefore, further linkage analysis was carried out with an additional 23 microsatellite markers. The results of further mapping on Chr 2 are shown in Table 4, and the distribution of haplotypes is shown in Fig. 4. Twenty recombination events among loci were observed in 332 samples. All 20 offspring arose as a result of a single crossover event. Analysis of the haplotype distribution pattern allowed the localization for the cataract gene ( $m c t$ ) to the $3.91 \mathrm{cM}$ region between D2Mit467 and D2Mit320 (Fig. 5).

\section{DISCUSSION}

The morphology of mouse cataracts takes four major forms: nuclear, cortical, capsular-epithelial and lens extrusion [21]. In the cataracts lens, various abnormal changes have been reported; the presence of cell nuclei in the lens fibers [6], the vacuolation of epithelial cells [20], degeneration of perinuclear fibers, and progressive condensation of the nucleus [17]. A cortical cataract involves the lens cortex and is associated with the breakdown of lens fiber cells, migration of lens nuclei to the posterior lens cortex, and abnormal fiber production [21]. Singh et al. [20] reported that lens epithelial cells damaged by intracellular vacuole formation invariably result in cortical and posterior subcapsular cataract formation. In 5-week-old cataract mice, the eyes did not show lens opacity on observation with the naked eye. On histological observation on the lens of 5week-old cataract mice, the lens nucleus was normal and the anterior cortical lens fibers were swollen. In the lens of 5month-old cataract mice, the lens nucleus was abnormally stained with eosin and was dislocated to the posterior cortex. Vacuolated epithelial cells covered the anterior surface of the lens. These results suggest that abnormal lens features in cataract mice occur at least 5 weeks after birth, and they resemble those in cortical cataracts.

Aphakia cataract $(a k)$ is characterized by closed eyelids, dysgenetic lens cataract $(d y l)$ by cornea-lens attachment, and vacuolated lens cataract $(v l)$ by spina bifida [21]. The three cataract models are cortical cataracts caused by a recessive gene. In the present study, however, the cataract mice displayed none of the features observed in these three cataract models. Therefore, the present mice represent a novel cataract model.

Congenital cataracts have been identified with all three types of Mendelian inheritance, i.e., autosomal dominant, autosomal recessive and $\mathrm{X}$-linked $[8,19]$. In the present study, the incidence of cataract in heterozygous mutants between the cataract and wild-type ddY mice was $0 \%$ and no difference in incidence was observed between males and females. These results indicate that the mutation in the cataract mice is autosomal recessive. In the offspring between the heterozygous mutants, 45 mice displayed cataracts and 121 mice were healthy. This segregation ratio was well in line with the expected 1:3 ratio, based on the hypothesis that the expression of cataracts in the cataract mice is controlled by an autosomal recessive gene.

In this study, we found that the $m c t$ lies $3.91 \mathrm{cM}$ on $\mathrm{Chr} 2$ between D2Mit467 and D2Mit320 (Fig. 5). At present, the

Table 2. Breeding data showing segregation in mating the cataract and wild type ddY mice

\begin{tabular}{lccc}
\hline Matings & $\begin{array}{c}\text { Observed } \\
\text { (female, male) }\end{array}$ & $\begin{array}{c}\text { Affected } \\
(\text { female, male) }\end{array}$ & $\begin{array}{c}\text { Incidence }(\%) \\
(\text { female, male) }\end{array}$ \\
\hline $\begin{array}{l}\text { heterozygous mutants }(\mathrm{hm}) \\
\mathrm{hm} \times \mathrm{hm}\end{array}$ & $198(99,99)$ & $0(0,0)$ & $0(0,0)$ \\
& $166(74,92)$ & $45(19,26)$ & $27.1(25.7,28.2)$ \\
\hline
\end{tabular}


Table 3. Linkage analysis of cataract gene $(m c t)$ in affected backcross progenies at selected loci

\begin{tabular}{|c|c|c|c|c|c|c|}
\hline & \multirow[b]{2}{*}{ Symbol } & \multirow[b]{2}{*}{ cM Position } & \multicolumn{2}{|c|}{ Affected } & \multicolumn{2}{|c|}{$\chi^{2}$ analysis } \\
\hline & & & Homo $^{\text {a) }}$ & Hetero $^{\text {b) }}$ & $\chi^{2}$ value & $P$ value \\
\hline \multirow{4}{*}{ Chr1 } & D1Mit170 & 19.5 & 7 & 13 & 1.800 & 0.1797 \\
\hline & D1Mit10 & 56.6 & 6 & 14 & 3.200 & 0.0736 \\
\hline & D1Mit15 & 87.9 & 9 & 11 & 0.200 & 0.6547 \\
\hline & D1Mit17 & 106.3 & 10 & 10 & 0.000 & 1.0000 \\
\hline \multirow{4}{*}{$\mathrm{Chr} 2$} & $\mathrm{D} 2 \mathrm{Jpk} 4$ & 18 & 60 & 0 & 60.000 & 0.0000 \\
\hline & D2Nds1 & 53 & 45 & 15 & 15.000 & 0.0001 \\
\hline & D2Mit28 & 78.2 & 11 & 9 & 0.200 & 0.6547 \\
\hline & D2Mit25 & 102 & 11 & 9 & 0.200 & 0.6547 \\
\hline \multirow{3}{*}{ Chr3 } & D3Mit1 & 11.2 & 11 & $9-$ & $0 . \overline{200}$ & 0.6547 \\
\hline & D3Mit313 & 49.7 & 13 & 7 & 1.800 & 0.1797 \\
\hline & D3Mit38 & 70.3 & 12 & 8 & 0.800 & 0.3711 \\
\hline \multirow{3}{*}{ Chr4 } & D4Mit1 & 6.3 & 11 & 9 & 0.200 & 0.6547 \\
\hline & D4Mit322 & 35.7 & 8 & 12 & 0.800 & 0.3711 \\
\hline & D4Mit12 & 57.6 & 10 & 10 & 0.000 & 1.0000 \\
\hline \multirow{3}{*}{ Chr5 } & D5Mit4 & 20 & 14 & 6 & 3.200 & 0.0736 \\
\hline & D5Mit9 & 54 & 13 & 7 & 1.800 & 0.1797 \\
\hline & D5Mit51 & 81 & 8 & 12 & 0.800 & 0.3711 \\
\hline \multirow{3}{*}{ Chr6 } & D6Mit158 & 6 & 12 & 8 & 0.800 & 0.3711 \\
\hline & D6Mit16 & 30.5 & 9 & 11 & 0.200 & 0.6547 \\
\hline & D6Mit12 & 59.6 & 9 & 11 & 0.200 & 0.6547 \\
\hline \multirow{3}{*}{ Chr7 } & D7Mit228 & 18 & 12 & 8 & 0.800 & $\overline{0.3711}$ \\
\hline & D7Mit62 & 42.6 & 13 & 7 & 1.800 & 0.1797 \\
\hline & D7Mit14 & 69 & 11 & 9 & 0.200 & 0.6547 \\
\hline \multirow{3}{*}{ Chr8 } & $\overline{\mathrm{D}} \overline{\mathrm{M}} \overline{\mathrm{Mit}} 15 \overline{5}$ & $i$ & 26 & 14 & 3.600 & 0.0578 \\
\hline & D8Mit6 & 30 & 23 & 17 & 0.900 & 0.3428 \\
\hline & D8Mit55 & 62 & 13 & 7 & 1.800 & 0.1797 \\
\hline \multirow{3}{*}{ Chr9 } & 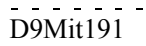 & 26 & 10 & $10^{-}$ & 0.000 & 1.0000 \\
\hline & D9Mit10 & 49 & 11 & 9 & 0.200 & 0.6547 \\
\hline & D9Mit19 & 71 & 12 & 8 & 0.800 & 0.3711 \\
\hline \multirow{4}{*}{ Chr10 } & D10Mit2 & $\overline{16}$ & 9 & 11 & 0.200 & 0.6547 \\
\hline & D10Mit11 & 50 & 26 & 14 & 3.600 & 0.0578 \\
\hline & D10Mit103 & 70 & 5 & 15 & 5.000 & 0.0253 \\
\hline & D11Mit51 & 18 & 10 & $10^{-}$ & 0.000 & 1.0000 \\
\hline \multirow[t]{2}{*}{ Chr11 } & D11Nds1 & 43.8 & 11 & 9 & 0.200 & 0.6547 \\
\hline & D11Mit10 & 63 & 11 & 9 & 0.200 & 0.6547 \\
\hline \multirow{2}{*}{ Chr12 } & D12Mit2 & 19 & 6 & $14^{-}$ & 3.200 & 0.0736 \\
\hline & D12Mit6 & 45 & 7 & 13 & 1.800 & 0.1797 \\
\hline \multirow{3}{*}{ Chr13 } & D13Mit117 & 19 & 25 & $15^{-}$ & 2.500 & 0.1138 \\
\hline & D13Mit9 & 45 & 11 & 9 & 0.200 & 0.6547 \\
\hline & D13Mit31 & 71 & 12 & 8 & 0.800 & 0.3711 \\
\hline \multirow{2}{*}{ Chr14 } & D14Mit4 & $\overline{16 . \overline{5}}$ & 9 & 11 & 0.200 & 0.6547 \\
\hline & D14Mit8 & 48.2 & 12 & 8 & 0.800 & 0.3711 \\
\hline & $\overline{\mathrm{D}} 15 \mathrm{Mit} 11$ & $-\overline{10 . \overline{4}}$ & 8 & $12^{-}$ & $0 . \overline{800}$ & $\overline{0.371 \overline{1}}$ \\
\hline Chr15 & D15Mit123 & 30.6 & 5 & 15 & 5.000 & 0.0253 \\
\hline & D15Mit40 & 65 & 11 & 9 & 0.200 & 0.6547 \\
\hline & D16Mit34 & $\overline{9} . \overline{6}$ & 12 & 8 & $0 . \overline{800}$ & $\overline{0.371 \overline{1}}$ \\
\hline Chr16 & D16Mit4 & 27.3 & 12 & 8 & 0.800 & 0.3711 \\
\hline & D16Mit94 & 57.6 & 24 & 16 & 1.600 & 0.2059 \\
\hline Chr17 & $\overline{\mathrm{D}} \overline{17 \mathrm{M}} \overline{\mathrm{M}} \mathrm{i} 1 \overline{6}$ & $\overline{1 \overline{7}} \overline{\overline{4}}$ & 10 & $10^{-}$ & 0.000 & 1.0000 \\
\hline Chrl/ & D17Mit20 & 34.3 & 11 & 9 & 0.200 & 0.6547 \\
\hline Chr18 & D18Mit14 & 18 & 10 & $10^{-}$ & 0.000 & 1.0000 \\
\hline Cnris & D18Nds1 & 55 & 5 & 15 & 5.000 & 0.0253 \\
\hline Chr19 & D19Mit60 & -15 & 7 & 13 & 1.800 & 0.1797 \\
\hline Chrig & D19Mit10 & 47 & 10 & 10 & 0.000 & 1.0000 \\
\hline
\end{tabular}

The location of markers and distance (cM) were cited from Mouse Genome [13].

a) Homo represent $m c t / m c t$ allele.

b) Hetero represent $m c t$ MSM allele. 
Table 4. Further linkage analysis of cataract gene on chr 2 of the cataract mice

\begin{tabular}{|c|c|c|c|c|}
\hline \multirow[t]{2}{*}{ Symbol } & \multirow[t]{2}{*}{ cM Position } & \multicolumn{2}{|c|}{ Affected } & \multirow{2}{*}{$\begin{array}{c}\chi^{2} \text { analysis } \\
\chi^{2} \text { value }\end{array}$} \\
\hline & & Homo $^{\text {a) }}$ & Hetero $^{\text {b) }}$ & \\
\hline D2Mit318 & 14.0 & 127 & 8 & 104.90 \\
\hline D2Mit521 & 15.3 & 127 & 8 & 104.90 \\
\hline D2Mit33 & 17.0 & 133 & 2 & 127.12 \\
\hline D2Mit120 & 17.0 & 130 & 5 & 115.74 \\
\hline D2Mit217 & 17.0 & 133 & 2 & 127.12 \\
\hline D2Mit234 & 17.0 & 133 & 2 & 127.12 \\
\hline D2Jpk4 & 18.0 & 173 & 2 & 167.09 \\
\hline D2Mit84 & 18.0 & 324 & 8 & 300.77 \\
\hline D2Mit235 & 22.5 & 325 & 7 & 304.59 \\
\hline D2Mit515 & 25.7 & 331 & 1 & 328.01 \\
\hline D2Mit367 & 26.2 & 329 & 3 & 320.11 \\
\hline D2Mit239 & 28.0 & 329 & 3 & 320.11 \\
\hline D2Mit204 & 28.0 & 330 & 2 & 324.05 \\
\hline D2Mit467 & 27.3 & 331 & 1 & 328.01 \\
\hline D2Mit320 & 27.3 & 320 & 12 & 285.73 \\
\hline D2Mit368 & 27.3 & 320 & 12 & 285.73 \\
\hline D2Mit370 & 27.3 & 166 & 9 & 140.85 \\
\hline D2Mit466 & 27.3 & 166 & 9 & 140.85 \\
\hline D2Mit203 & 28.0 & 329 & 3 & 320.11 \\
\hline D2Mit237 & 28.0 & 166 & 9 & 140.85 \\
\hline D2Mit88 & 30.0 & 164 & 11 & 133.77 \\
\hline D2Mit155 & 30.0 & 123 & 12 & 91.27 \\
\hline D2Mit269 & 30.0 & 125 & 10 & 97.96 \\
\hline D2Mit327 & 40.4 & 113 & 22 & 61.34 \\
\hline D2Nds1 & 53 & 101 & 34 & 33.25 \\
\hline
\end{tabular}

The location of markers and distance $(\mathrm{cM})$ were cited from Mouse Genome [13].

a) Homo represent $m c t / m c t$ allele.

b) Hetero represent $m c t /$ MSM allele.

bs (blind-sterile) and the Lop4 (lens opacity 4) genes are mapped on $\mathrm{Chr} 2$, and it is reported that the genes are causative of mouse cataracts. The $b s$ gene is $83 \mathrm{cM}$ from the centromere of $\mathrm{Chr} 2$, and it causes both cataracts and male sterility [25]. The Lop 4 gene is mapped $96 \mathrm{cM}$ from the centromere of $\mathrm{Chr} 2$. This gene acts through semidominant inheritance [26]. The Pax6 gene is mapped on $65 \mathrm{cM}$ from the centromere of Chr 2. Artificial mutatation of the Pax6 gene is reported to lead to the development of cataracts [3]. As determined by linkage analysis, the bs, Lop 4 and Pax6 genes, as well as the $m c t$ gene, all map to locations on $\mathrm{Chr} 2$. The $m c t$ gene, however, lies in a location distinct from the three known cataract genes; therefore, the $m c t$ gene is distinct from these three cataract genes.

One gene in the region between D2Mit467 and D2Mit320 that causes eye malfunction is the Icst (iris-corneal strands) gene. The position of the Icst gene has been widely mapped, within a $7 \mathrm{cM}$ region on both sides of D2Mit365 $(21.9 \mathrm{cM})$; thus, the physical-location of the Icst gene is uncertain. Mutations in Icst cause various eye diseases, but there have been no reports on a potential role in cataract development [24]. As the gene that causes cataracts is not reportedly localized to the area where the causative genes for cataracts are known to exist, we believe that the $m c t$ is a novel cata-
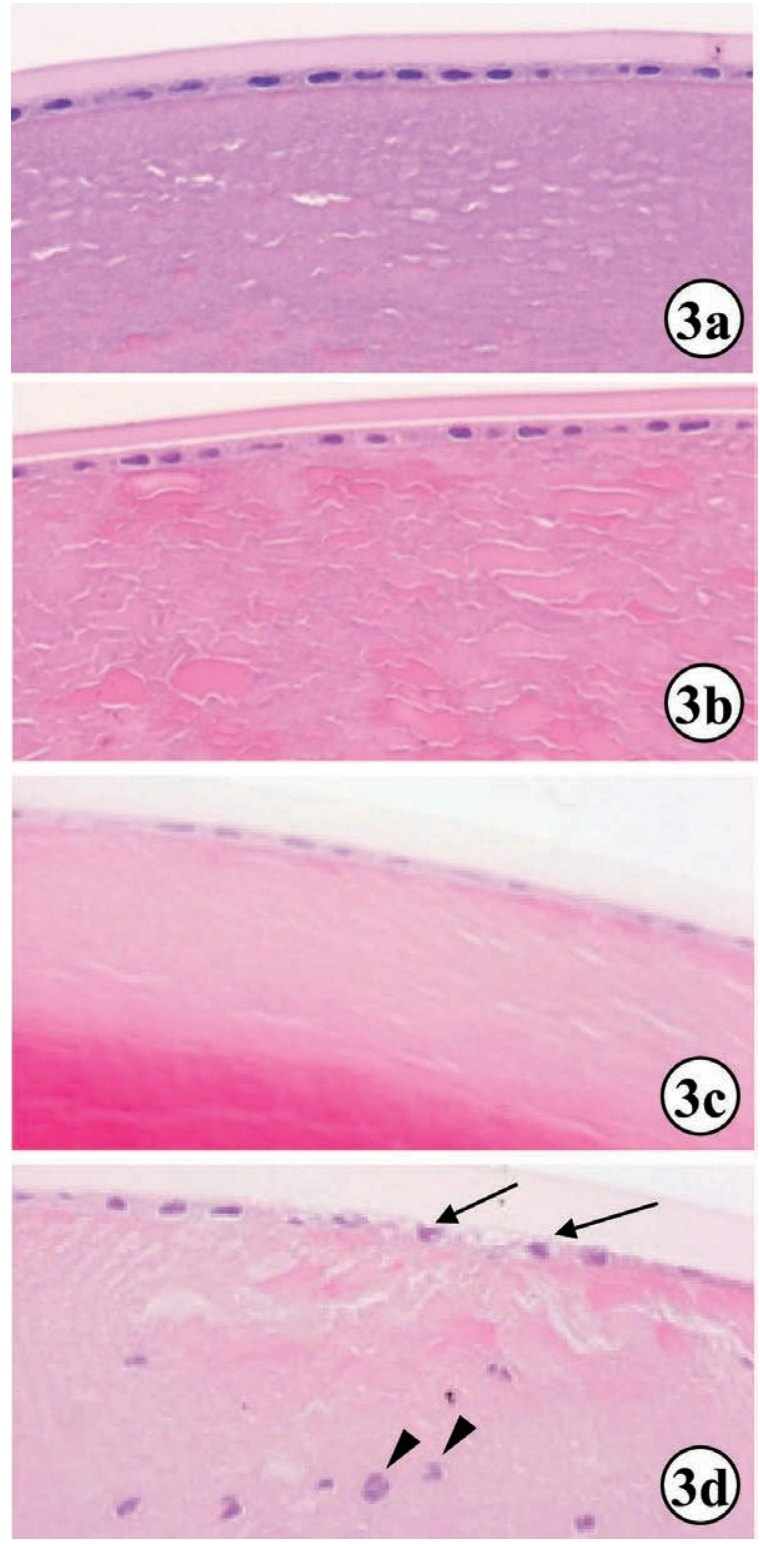

Fig. 3. Anterior region of the lens cortex of wild-type ddY and cataract mice $(\times 340)$. In the 5-week-old wild-type ddY mouse, no marked changes are seen in the lens cortex (3a). In the 5-week-old cataract mouse, swollen fibers are seen in the lens cortex (3b). The anterior surface of the lens in the 5month-old wild-type mouse is covered with a simple cuboidal epithelium (3c). In the 5-month-old cataract mouse, however, vacuolated epithelial cells (arrows) are seen in the simple cuboidal epithelium (3d). Furthermore, pyknotic nuclei (arrowheads) and disrupted arrangement of the lens fibers are seen in the anterior region (3d).

ract gene.

The present cataract mice are fully viable and fertile, and a spontaneous cataract model derived from ddY mice has not yet been reported. This cataract mouse is thus a novel 
D2Mit84

D2Mit235

$\mathrm{D} 2 \mathrm{Mit} 367 \cdot 239 \cdot 203$

D2Mit204

D2Mit515:467

D2Mit320 368

$\begin{array}{llllllll}0 & 312 & 12 & 1 & 1 & 1 & 4 & 1\end{array}$

Fig. 4. Distribution of haplotypes in a set of 332 affected offspring from the backcross [cataract mouse $\times$ (cataract mouse $\times \mathrm{MSM} / \mathrm{Ms}$ mouse)]. Typed loci are listed on the left. Columns denote specific chromosomes identified in affected backcross progenies. Black squares represent the $m c t /$ MSM allele; White squares represent the $m c t / m c t$ allele.

\section{Chromosome 2}

Marker Centromere Distance ( cM )

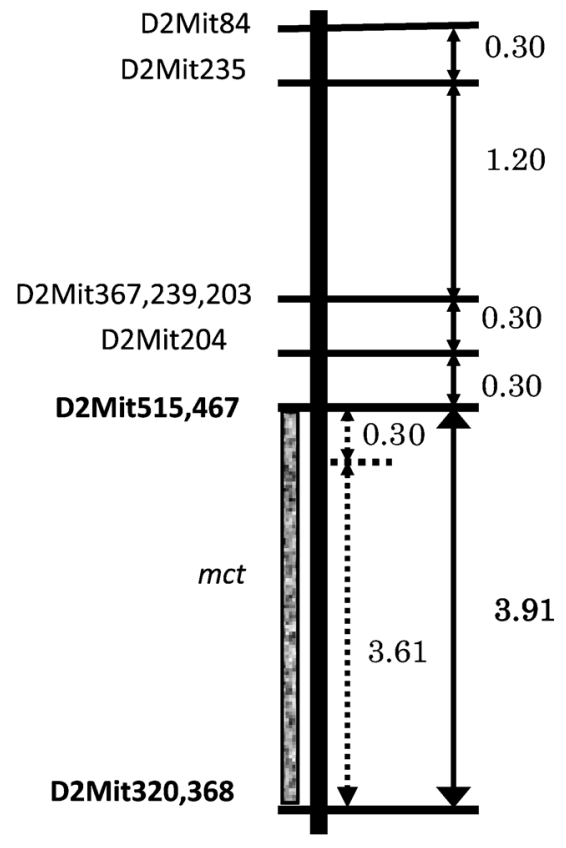

Fig. 5. Genetic linkage map of $\mathrm{Chr}$ 2. The map shows the chromosomal location of $m c t$ and other loci typed in the interspecific backcross with distances between loci given by recombination value. Typed loci are listed on the left of the chromosome and values to the right are distances between loci. model that will be a good tool for genetic analysis and for the study of the molecular biology of cataractogenesis. We have designated the present cataract mouse as the Morioka (MCT) mouse.

ACKNOWLEGMENT(S). This work was supported in part by a Grant-in Aid (No. 16580253) from the Ministry of Education, Science and Culture of Japan.

\section{REFERENCES}

1. Arkin, M., Azar, D. and Fraioli, A. 1992. Infantile cataracts. Int. Ophthalmol. Clin. 32: 107-120.

2. Bermejo, E. and Martínez-Frías, M. L. 1998. Congenital eye malformations: clinical-epidemiological analysis of 1,124,654 consecutive births in Spain. Am. J. Med. Genet. 75: 497-504.

3. Duncan, M., Cvekl, A., Li, X. and Piatigorsky, J. 2000. Truncated forms of Pax-6 disrupt lens morphology in transgenic mice. Invest. Ophthalmol. Vis. Sci. 41: 464-473.

4. Eckstein, M., Vijayalakshmi, P., Killedar, M., Gilbert, C. and Foster, A. 1996. Aetiology of childhood cataract in south India. Br. J. Ophthalmol. 80: 628-632.

5. Graw, J. 2004. Congenital hereditary cataracts. Int. J. Dev. Biol. 48: 1031-1044.

6. Graw, J., Neubaüser-Klaus, A., Löster, J. and Favor, J. 2002. A 6-bp deletion in the Crygc gene leading to a nuclear and radial cataract in the mouse. Invest. Ophthalmol. Vis. Sci. 43: 236240.

7. Hamai, Y., Fukui, H. N. and Kuwabara, T. 1974. Morphology of hereditary mouse cataract. Exp. Eye Res. 18: 537-546.

8. He, W. and Li, S. 2000. Congenital cataracts: gene mapping. Human Genet. 106: 1-13.

9. Jensen, S. and Goldschmidt, E. 1971. Genetic counselling in sporadic cases of congenital cataract. Acta Ophthalmol. 49: 572-576.

10. Kang, M., Cho, J. W., Kim, J. K., Kim, E., Kim, J. Y., Cho, K. H., Song, C. W. and Yoon, S. K. 2008. Fine localization of a new cataract locus, $\mathrm{Kec}$, on mouse chromosome 14 and exclusion of candidate genes as the gene that causes cataract in the Kec mouse. BMP Rep. 41: 651-656.

11. Kohale, K., Ingle, A., Kelkar, A. and Parab, P. 2004. Dense cataract and microphthalmia-New spontaneous mutation in BALB/c mice. Comp. Med. 54: 275-279.

12. Liu, Y., Zhang, X., Luo, L., Wu, M., Zeng, R., Cheng, G., Hu, B., Liu, B., Liang, J. J. and Shang, F. 2006. A novel $\alpha$ B-crystallin mutation associated with autosomal dominant congenital lamellar cataract. Invest. Ophthalmol. Vis. Sci. 47: 1069-1075.

13. Lyon, M. F. and Kirby, M. C. 1994. Mouse chromosome atlas. Mouse Genome 92: 14-61.

14. Lyon, M. F., Jarvis, S. E., Sayers, I. and Holmes, R. S. 1981. Lens opacity: a new gene for congenital cataract on chromosome 10 of the mouse. Genet. Res. 38: 337-341.

15. Maeda, Y. Y., Funata, N., Takahama, S., Sugata, Y. and Yonekawa, H. 2001. Two interactive genes responsible for a new inherited cataract (RCT) in the mouse. Mamm. Genome 12: $278-283$.

16. Muggleton-Harris, A. L., Festing, M. F. W. and Hall, M. 1987. A gene location for the inheritance of the cataract Fraser $\left(\mathrm{Cat}^{\mathrm{Fr}}\right)$ mouse congenital cataract. Genet. Res. 49: 235-238.

17. Narita, M., Wang, Y., Kita, A., Omi, N., Yamada, Y. and Hiai, H. 2002. Genetic analysis of Nakano cataract and its modifier genes in mice. Exp. Eye Res. 75: 745-751. 
18. Okamura, T., Miyoshi, I., Takahashi, K., Mototani, Y., Ishigaki, S., Kon, Y. and Kasai, N. 2003. Bilateral congenital cataracts result from a gain-of-function mutation in the gene for aquaporin-0 in mice. Genomics 81: 361-368.

19. Shiels, A. and Hejtmancik, F. 2007. Genetic origins of cataract. Arch. Ophthalmol. 125: 165-173.

20. Singh, D. P., Guru, S. C., Kikuchi, T., Abe, T. and Shinohara, T. 1995. Autoantibody against $\beta$-crystallins induce lens epithelial cell damage and cataract formation in mice. J. Immunol. 155: 993-999.

21. Smith, R. S., Sundberg, J. P. and Linder, C. C. 1997. Mouse mutation as model for studying cataracts. Pathobiology 65 : 146-154.

22. Song, C. W., Okumoto, M., Mori, N., Yamate, J., Sakuma, S., Kim, J. S., Han, S. S., Hilgers, J. and Esaki, K. 1997. A new hereditary cataract mouse with lens rupture. Lab. Anim. 31:
$248-253$.

23. Teramoto, Y., Uga, S., Matsushima, Y., Shimizu, K., Morita, T. and Shirakawa, S. 2000. Morphological study on rupture of posterior capsule in RLC mouse lens. Graefe's. Arch. Clin. Exp. Ophthalmol. 238: 970-978.

24. Thaung, C., West, K., Clark, B. J., McKie, L., Morgan, J. E., Arnold, K., Nolan, P. M., Peters, J., Hunter, A. J., Brown, S. D., Jackson, I. J. and Cross, S. H. 2002. Novel ENU-induced eye mutations in the mouse: models for human eye disease. Hum. Mol. Genet. 11: 755-767.

25. Varnum, D. S. 1983. Blind-sterile: a new mutation on chromosome 2 of the house mouse. J. Hered. 74: 206-207.

26. West, J. D. and Fisher, G. 1986. Further experience of the mouse dominant cataract mutation test from an experiment with ethylnitrosourea. Mutat. Res. 164: 127-136. 